\title{
CLADOCERA (BRANCHIOPODA: ANOMOPODA, CTENOPODA, AND ONYCHOPODA) FROM SICILIAN INLAND WATERS: AN UPDATED INVENTORY
}

BY

\author{
FEDERICO MARRONE ${ }^{1}$ ), ROSSELLA BARONE and LUIGI NASELLI-FLORES
}

Dipartimento di Scienze Botaniche, Università di Palermo, Via Archirafi, 38, I-90123 Palermo, Italy

\begin{abstract}
An extensive survey aimed at updating and increasing the knowledge on species richness and distribution of Cladocera (Branchiopoda) in Sicily has been carried out in the period 2000-2004. More than 250 water bodies, mainly temporary, have been sampled on the whole Sicilian territory and the circum-Sicilian islands. This sampling effort led to the discovery of several species new to the fauna of the island and, coupled with a careful bibliographic review, allowed the realization of an updated checklist that includes 57 species definitely present on the island (only 33 were formerly known), and two more, whose actual presence in Sicily is dubious and needs confirmation. The chorological spectrum of the Sicilian cladoceran fauna shows a predominance of taxa with a wide distribution, but several others with a strictly Mediterranean range are also present. A slightly major affinity of the Sicilian cladoceran fauna with the Tunisian one, rather than with that inhabiting the water bodies of the Italian mainland, was observed. Moreover, the lack of detailed information on cladoceran species richness and composition in Tunisia does not allow to determine a definitive outline of the affinities and origins of the fauna on the island. Nevertheless, the island, located in the middle of the Mediterranean basin, represents a pivotal point in this area, characterized by high biodiversity indices.
\end{abstract}

\section{RIASSUNTO}

Tra il 2000 ed il 2004 è stata condotta una campagna di studi finalizzata ad aggiornare ed incrementare le conoscenze sulla ricchezza specifica e sulla diversità dei cladoceri (Branchiopoda) siciliani. Sono stati campionati più di 250 bacini, dall'idroperiodo temporaneo o permanente, in Sicilia e nelle isole circumsiciliane. Questo sforzo di campionamento ha portato al rinvenimento di numerose entità nuove per l'isola e, affiancato ad una revisione accurata della bibliografia esistente, ha portato alla redazione di una checklist aggiornata che comprende 57 specie presenti con certezza in Sicilia (a fronte delle 33 conosciute in precedenza) e altre due la cui presenza attuale in Sicilia è dubbia e necessita di conferme. Lo spettro corologico della fauna a cladoceri siciliana mostra la predominanza di taxa dall'ampia distribuzione, ma sono presenti numerosi taxa ad areale strettamente mediterraneo. E'stata osservata una affinità leggermente maggiore della fauna

1) Corresponding author; e-mail: federico.marrone@neomedia.it

(C) Koninklijke Brill NV, Leiden, 2006

Crustaceana 78 (9): 1025-1039

Also available online: www.brill.nl 
a cladoceri siciliana con quella tunisina rispetto che con quella dell'Italia peninsulare. Purtroppo l'assenza di informazioni dettagliate riguardanti i cladoceri tunisini non permette di avere un quadro chiaro delle origini e delle affinità della fauna dell'isola. Ad ogni modo, la Sicilia, posta al centro del bacino del Mediterraneo, rappresenta un punto nodale in una area caratterizzata da elevati valori di biodiversità.

\section{INTRODUCTION}

Although the location of Sicily in the Mediterranean basin makes it a potential transition zone for freshwater taxa with different chorological tendencies (NaselliFlores et al., 1998), to date little attention has been paid to the knowledge of Sicilian freshwater microcrustaceans. The purpose of this paper is to provide an updated checklist of Sicilian cladocerans that summarizes all available data from a review of the existing literature and available collections, and from a five-year field survey.

The first information on Sicilian freshwater Cladocera was reported by Moniez (1889) and later by Berzins (1954), both on the microinvertebrates of some water bodies on eastern Sicily. Their papers, based on incidental collections, lack illustrations and most of the cladocerans they report have never been found again on the island. Faranda (1977) mentioned some species found during a study aimed at finding suitable aquaculture sites.

More exhaustive studies are those carried out by Margaritora et al. (1982). These authors presented the first detailed contribution to the knowledge of the Sicilian entomostracan fauna. Their data, along with those on cladocerans from Sicilian lakes and reservoirs with a surface area larger than $0.2 \mathrm{~km}^{2}$ (Calvo et al., 1993), were summarized by Cottarelli et al. (1995) and Naselli-Flores et al. (1998).

From autumn 2000 to winter 2004/2005, further investigations have been conducted with special attention for the Branchiopoda, Copepoda, and Ostracoda of lentic water bodies. The first results (Marrone, 2003a, b; Marrone \& NaselliFlores, 2004, 2005; Castelli et al., 2006; Marrone et al., 2006) showed that entomostracan species richness in Sicily has been undervalued by the Italian checklists (Argano et al., 1995; Cottarelli et al., 1995) and that our knowledge of the Cladocera on Sicily is still incomplete. The present paper is aimed at updating the inventory of Sicilian cladocerans on the basis of both published and original data.

Data have been collected through field and bibliographical research. All species cited in the literature have been searched for in order to check their actual presence 


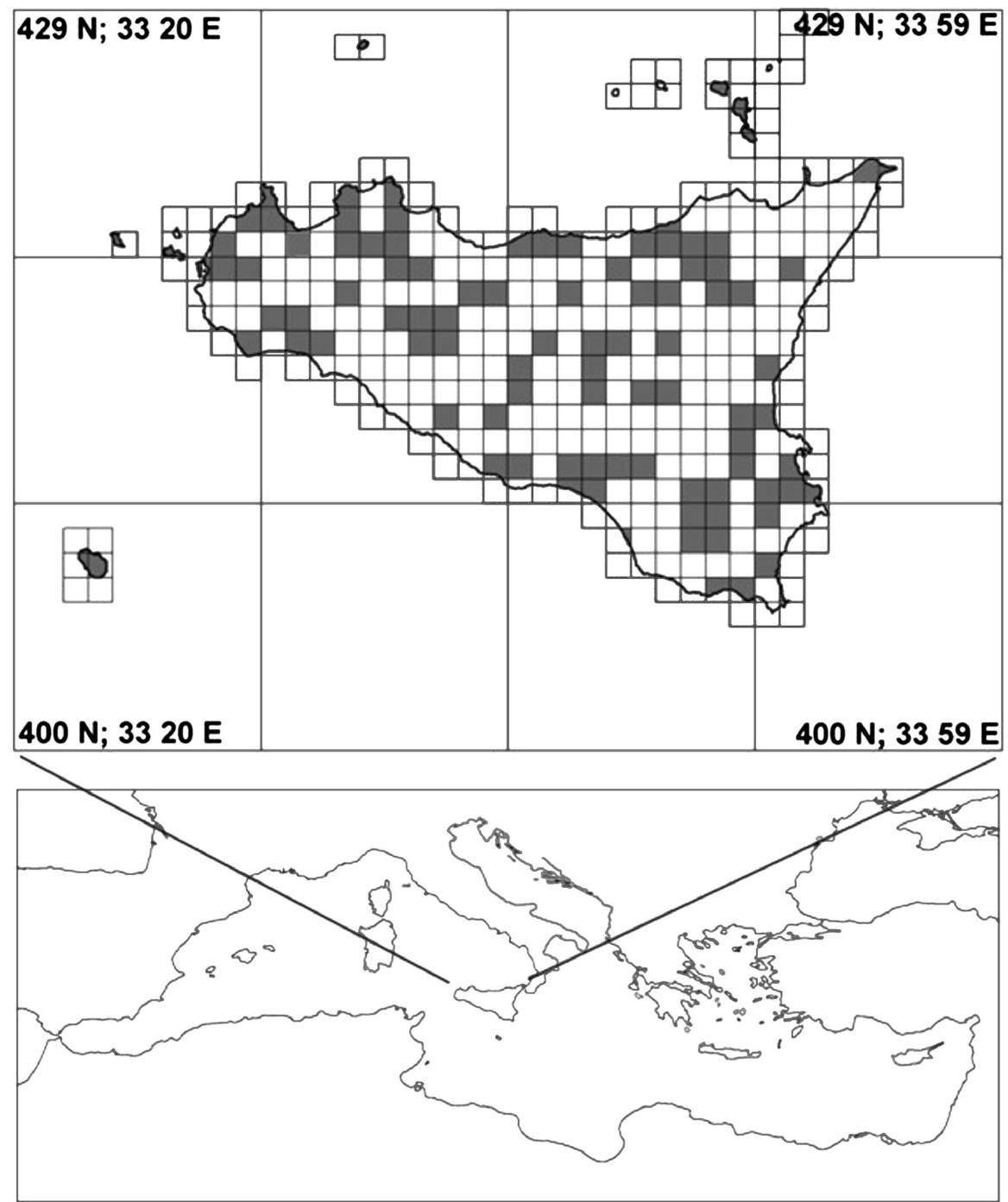

Fig. 1. Location of the studied sites in Sicily. In the figure, the Pelagie Islands are not displayed but they were extensively sampled. Coordinates are given according to the UTM system, map datum WGS84.

on the island. In addition, a review of the freshwater zooplankton collection stored at the Department of Botanical Sciences of the University of Palermo was carried out.

More than 250 temporary and permanent water bodies, spread all over the Sicilian mainland and circum-Sicilian islands (fig. 1), have been sampled by means of hand nets and towing nets with $200 \mu \mathrm{m}$ and $80 \mu \mathrm{m}$ mesh size, respectively. To get a picture of the sampled environment as complete as possible, particular 
attention was paid to sample in the open waters as well as near the bottom of water bodies and among vegetation. When the use of nets was impossible, water was collected with a flask and filtered on a $200 \mu \mathrm{m}$ mesh sieve. Samples were partly fixed in situ with $80 \%$ ethanol or $4 \%$ buffered formaldehyde and stored in the authors' collection. A sub-sample was kept alive and the organisms put in culture to observe the ontogenetic phases of selected species.

Identification of organisms followed Smirnov (1974, 1992, 1996), Margaritora (1985), Korovchinsky (1992), Alonso (1996), Kotov (1999), Orlova-Bienkowskaja (2001), and Benzie (2005).

SEM observations were carried out and micrographs were taken using a Zeiss LEO 420.

In this paper, the checklist of the Cladocera is organized according to the criteria adopted by Mouelhi et al. (2000) with some minor modifications.

In the inventory, the classification follows Alonso (1996), with the exception of the Chydoridae, which are reported according to Dumont \& Negrea (2002).

The similarity between the Sicilian cladoceran fauna and those up to now known for the Italian mainland and Tunisia, was calculated according to the Sörensen Index (Magurran, 1988):

$$
I=2 c /(a+b)
$$

where $I$ is the identity between the faunas, expressed in $\%$; $a$ is the number of taxa in fauna "a"; $b$ is the number of taxa in fauna " $b$ "; and $c$ is the number of taxa common to both faunas.

\section{INVENTORY}

The name of the species is followed by two letters in braces, indicating the location where each taxon was collected $(\{\mathrm{SM}\}$ for Sicilian mainland, $\{\mathrm{EO}\}$ for Eolian Archipelago, $\{\mathrm{EG}\}$ for Egadi Islands and "Isole dello Stagnone", $\{\mathrm{US}\}$ for Ustica island, and $\{\mathrm{PP}\}$ for the Pelagie Archipelago and Pantelleria island). In the same way, the reference to the first finding of the taxon in Sicily is indicated in square brackets. If the species has been collected and identified again after its first record in Sicily, $[\mathrm{R}]$ follows the reference of its first finding. If the species has been collected also in the frame of the present work, [RP] follows the reference. Each species is followed by the synonyms (in small type) with which it has been reported for the island, if applicable.

Class BRANCHIOPODA Latreille, 1817

Order CTENOPODA G. O. Sars, 1865

Family SIDIDAE Baird, 1850 
Genus Diaphanosoma Fischer, 1850

D. lacustris Kořinek, 1981 \{SM\} [Margaritora et al., 1982] [RP] Diaphanosoma leuchtenbergianum Fischer, 1850

D. brachyurum (Liévin, 1848) \{SM $\}$ [Faranda, 1977] [R]

Order ANOMOPODA G. O. Sars, 1865

Family DAPHNIIDAE Strauss, 1820

Genus Daphnia O. F. Müller, 1785

Subgenus Daphnia O. F. Müller, 1785

D. (D.) ambigua Scourfield, 1947 \{SM\} [Calvo et al., 1993] [RP]

D. (D.) cucullata G. O. Sars, 1862 \{SM\} [Calvo et al., 1993] [RP]

D. (D.) curvirostris Eylmann, 1887 \{SM\} [Present work] [RP]

D. (D.) galeata G. O. Sars, 1863 \{SM\} [Present work] [RP]

D. (D.) hyalina Leydig, 1860 \{SM\} [Calvo et al., 1993] [RP]

D. (D.) longispina (O. F. Müller, 1776) \{SM\} [Berzins, 1954] [RP]

D. (D.) obtusa Kurz, 1875 \{SM\} [Margaritora et al., 1982] [RP]

D. (D.) parvula Fordyce, 1901 \{SM\} [Present work] [RP]

D. (D.) pulex Leydig, 1860 \{SM\} [Margaritora et al., 1982] [RP]

D. (D.) rosea G. O. Sars, 1862 \{SM\} [Margaritora et al., 1982] [RP] Subgenus Ctenodaphnia Dybowski \& Grochowski, 1895

D. (C.) atkinsoni Baird, 1859 \{SM, EG\} [Marrone, 2003b] [RP]

D. (C.) chevreuxi Richard, 1896 \{SM\} [Margaritora et al., 1982] [RP]

D. (C.) magna Strauss, 1820 \{SM\} [Margaritora et al., 1982] [RP]

D. (C.) mediterranea Alonso, 1985 \{EO, EG\} [Present work] [RP]

Genus Simocephalus Schödler, 1858

S. congener (Koch, 1841) \{SM $\}$ [Margaritora et al., 1982] [RP]

S. exspinosus var. congener

S. exspinosus (De Geer, 1778) \{SM $\}$ [Margaritora et al., 1982] [RP]

S. vetulus (O. F. Müller, 1776) \{SM\} [Moniez, 1889] [RP]

Genus Ceriodaphnia Dana, 1853

C. dubia Richard, 1894 \{SM\} [Margaritora et al., 1982] [RP]

C. laticaudata P. E. Müller, 1867 \{SM, EG\} [Margaritora et al., 1982] [RP]

C. pulchella G. O. Sars, 1862 \{SM\} [SM] [Berzins, 1954] [R]

C. quadrangula O. F. Müller, 1785 \{SM, EG, PP\} [Margaritora et al., 1982]

[RP]

C. reticulata (Jurine, 1820) \{SM\} [Margaritora et al., 1982] [RP]

Genus Scapholeberis Schödler, 1858

S. rammneri Dumont \& Pensaert, 1983 [SM\} [Marrone, 2003b] [RP] 
Genus Bosmina Baird, 1846

B. longirostris (O. F. Müller, 1776) \{SM $\}$ [Faranda, 1977] [RP]

B. longirostris var. curvirostris

Family MoINIDAE Goulden, 1968

Genus Moina Baird, 1850

M. brachiata (Jurine, 1820) \{SM, US, EG\} [Margaritora et al., 1982] [RP]

M. macrocopa (Strauss, 1819) \{SM\} [Present work] [RP]

M. salina Daday, 1888 \{SM\} [Marrone, 2003b] [RP]

Family MACROTRICHIDAE Norman \& Brady, 1867

Genus Macrothrix Baird, 1843

M. groenlandica Lilljeborg, 1900 \{SM\} [Present work] [RP]

M. hirsuticornis Norman \& Brady, 1867 \{SM, PP\} [Berzins, 1954] [RP]

M. lathonura [? sic]

M. laticornis (Jurine, 1820) \{SM\} [Marrone, 2003b] [RP]

Macrothrix sp. \{US\} [Marrone, 2003a] [RP]

Family CHYDORIDAE Dybowski \& Grochowski, 1894 Subfamily Chydorinae Dybowski \& Grochowski, 1894 Genus Pleuroxus Baird, 1843

P. aduncus (Jurine, 1820) \{SM\} [Margaritora et al., 1982][RP]

P. letourneuxi (Richard, 1888) \{SM, EG\} [Margaritora et al., 1982] [RP]

P. laevis G. O. Sars, 1861 \{SM\} [Berzins, 1954]

Genus Disparalona Fryer, 1968

D. rostrata (Koch, 1844) \{SM\} [Berzins, 1954] [RP]

Genus Alonella G. O. Sars, 1862

A. excisa (S. Fischer, 1854) \{SM\} [Margaritora et al., 1982] [RP]

A. exigua (Lilljeborg, 1853) \{SM $\}$ [Moniez, 1889]

A. nana (Baird, 1850) \{SM\} [Moniez, 1889]

Genus Chydorus Leach, 1816

C. sphaericus (O. F. Müller, 1776) \{SM, PP $\}$ [Moniez, 1889] [RP]

C. ovalis Kurz, 1875

C. ovalis Kurz, 1875 \{SM\} [Margaritora, unpubl. data]

Genus Dunhevedia King, 1853

D. crassa King, 1853 \{SM\} [Margaritora et al., 1982] [RP]

Subfamily Aloninae Frey, 1967

Genus Alona Baird, 1843

A. affinis (Leydig, 1860) \{SM\} [Present work] [RP]

A. costata G. O. Sars, 1862 \{SM\} [Moniez, 1889] [R] 
A. elegans Kurz, 1875 \{SM, US, EG, PP\} [Margaritora et al., 1982] [RP]

A. elegans arcuata Herbst, 1964

A. guttata G. O. Sars, 1862 \{SM\} [Marrone, 2003b] [RP]

A. nuragica Margaritora, 1971 \{SM\} [Marrone, 2003b] [RP]

A. rectangula G. O. Sars, 1862 \{SM\} [Margaritora et al., 1982] [RP]

Alona sp. \{SM $\}$ [Present work] [RP]

Genus Kurzia Dybowski \& Grochowski, 1894

K. latissima (Kurz, 1875) \{SM\} [Moniez, 1889]

Genus Leydigia Kurz, 1875

L. acanthocercoides (Fischer, 1854) \{SM $\}$ [Present work] [RP]

L. leydigi (Schödler, 1862) \{SM\} [Margaritora et al., 1982] [RP]

L. quadrangularis (Leydig, 1860)

Genus Oxyurella Dybowski \& Grochowski, 1894

O. tenuicaudis (G. O. Sars, 1862) \{SM\} [Margaritora et al., 1982] [RP] Genus Tretocephala Frey, 1965

T. ambigua (Lilljeborg, 1900) \{SM $\}$ [Margaritora et al., 1982] [RP]

Genus Graptoleberis G. O. Sars, 1862

G. testudinaria (S. Fischer, 1848) \{SM $\}$ [Moniez, 1889] [R]

Order ONYCHOPODA Sars, 1865

Family POLYPHEMIDAE Baird, 1845

Genus Polyphemus O. F. Müller, 1776

P. pediculus (Linnaeus, 1758) \{SM [Moniez, 1889] [R]

\section{NOTES ON THE INVENTORY}

In all, 57 species belonging to 20 genera and seven families of the superorder Cladocera are to date recorded on Sicily. To these should be added Eurycercus lamellatus (O. F. Müller, 1776), which was reported by Moniez (1889) on the basis of a single carapace collected in "Lago di Lentini" and never found again, and Moina affinis Birge, 1893, whose incidental finding in Pantano Longarini (southeastern Sicily) (Faranda, 1977) is rather dubious and needs confirmation. Five species, Pleuroxus laevis, Alonella exigua, A. nana, Chydorus ovalis, and Kurzia latissima, have never been found again after their first report from the island; five more, Diaphanosoma brachyurum, Ceriodaphnia pulchella, Graptoleberis testudinaria, Alona costata, and Polyphemus pediculus, could not be found in the framework of the present survey, but have been reported by at least two different authors.

The present paper reports 24 species more than do Cottarelli et al. (1995), who compiled the Italian checklist. Nine of these are here noted on the basis of original data: Daphnia (Daphnia) curvirostris, D. (D.) galeata, D. (D.) parvula, D. (Ctenodaphnia) mediterranea (Daphniidae); Moina macrocopa (Moinidae); 
Macrothrix groenlandica (Macrotrichidae); Alona sp., A. affinis, and Leydigia acanthocercoides (Chydoridae).

Among the Ctenopoda, only two representatives of the family Sididae have been found. While Diaphanosoma lacustris has been collected several times in many of the permanent reservoirs of the island (cf. Calvo et al., 1993; Naselli-Flores \& Barone, 1997; Naselli-Flores et al., 1998), D. brachyurum has been found only twice (Faranda, 1977; Margaritora et al., 1982) and its actual presence on Sicily needs confirmation. Moreover, from the sites reported by Faranda (1977), only D. lacustris has been collected in the last 20 years, and on the site reported by Margaritora et al. (1982) several samples did not yield any Ctenopoda at all.

In Sicily, the most species-rich families of the order Anomopoda are the Daphniidae and Chydoridae, with 23 species each, followed by the Moinidae and Macrotrichidae, with 4 species each, and the Bosminidae, represented only by Bosmina longirostris.

Two allochthonous taxa belong to this order: Daphnia (Daphnia) ambigua and $D$. (D.) parvula, whose invasion in Europe from the second half of the $20^{\text {th }}$ century is well documented (Flössner, 2000). Both of these were already known to be present in Italy (Margaritora, 1985; Riccardi et al., 2004).

The absence from the island of some species (e.g., Daphnia (Ctenodaphnia) similis Claus, 1876, Megafenestra aurita (S. Fischer, 1849), and Moina micrura Kurz, 1875) known to occur in both North Africa and Europe, is likely due to a lack of data, and further sampling campaigns may possibly reveal their presence in Sicily as yet.

Among the Onychopoda, only Polyphemus pediculus has been found. It has been reported by Moniez (1889) and Faranda (1977) in permanent swamps of southeastern Sicily.

\section{NOTES ON GEOGRAPHICAL DISTRIBUTION}

As expected, the chorological spectrum of Sicilian cladocerans (fig. 2) shows a clear predominance of taxa with a wide distribution range (i.e., present in at least three biogeographical regions), followed by Palaearctic elements and Mediterranean ones, thus suggesting the absence of a strongly characterized Mediterranean cladoceran fauna. The most typical Mediterranean elements of the Sicilian Cladocera fauna are Daphnia (Ctenodaphnia) mediterranea, D. $(C$.) chevreuxi, Moina salina, Pleuroxus letourneuxi, and Alona nuragica. To those species should be added two taxa currently under study, Macrothrix sp. and Alona sp., potentially endemic to Sicily. All these taxa are strictly linked with temporary or astatic water bodies, which prove to represent the most expressive and significant inland water typology in the island. A survey aimed towards a 


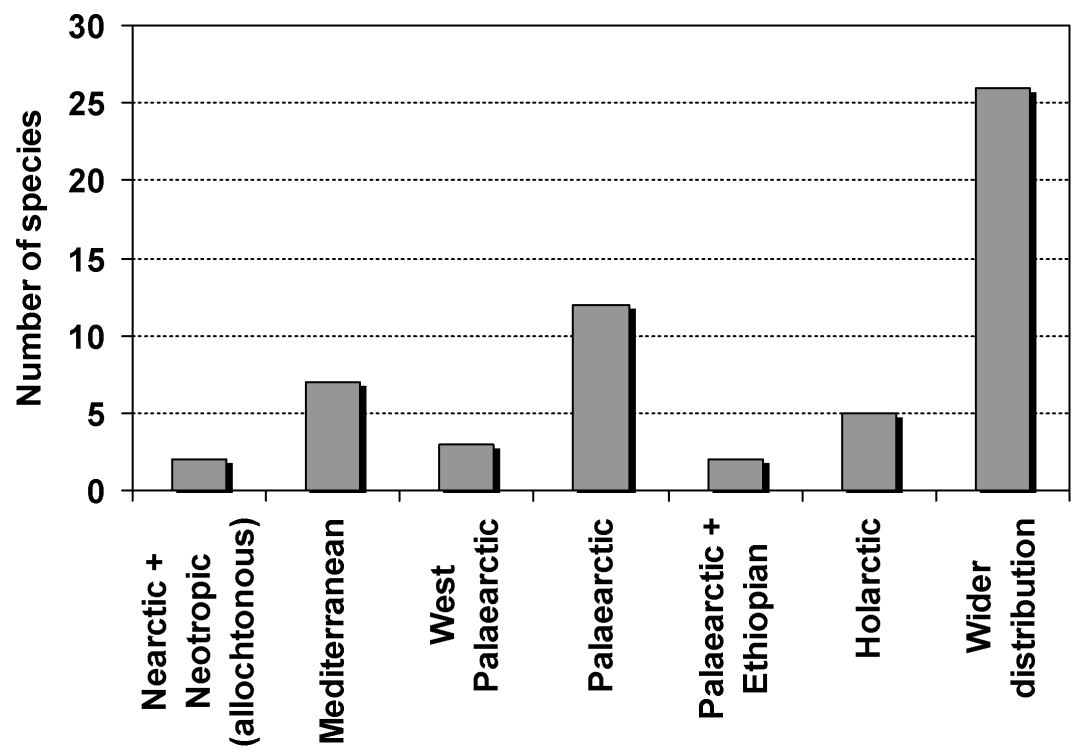

Fig. 2. Chorological spectrum of the Sicilian Cladocera.

characterization of the Sicilian inland waters (Marrone et al., 2005), showed a clear spatial segregation from the "temperate" taxa with a northern, and the "steppic" ones with a southern affinity; the former ones being limited to higher altitudes as already observed in Maghreb (Mouehli et al., 2000).

Moreover, further affinities are evident from the values obtained by calculating the Sörensen similarity index. This shows a value between Sicilian and Tunisian cladoceran faunas $(61.7 \%)$ similar to that calculated between Sicilian and Italian mainland faunas $(60.5 \%)$. Unfortunately, current knowledge on Tunisian cladocerans, mainly based on the works by Gurney (1909), Gauthier (1928), Dumont et al. (1979), and Mouelhi et al. (2000), is far from being exhaustive and this gap in our present-day knowledge precludes a clear weighing of the northern and southern influences on the island. Yet, the two similarity values are very close, and considering that the similarity between Tunisia and the Italian mainland accounts for a $41.6 \%$, the island can be regarded as a bridge between Europe and North Africa.

\section{NOTES ON RARE OR CONTROVERSIAL SPECIES}

\section{Daphnia (Ctenodaphnia) mediterranea Alonso, 1985}

This is a taxon typical of brackish temporary to semi-permanent swamps. It is known to occur in Spain (Alonso, 1985), Morocco (Mouelhi et al., 2000), and Sardinia (Margaritora, 1985), while its presence in Rumania has to be checked 
(Alonso, 1985). Its finding in two astatic brackish ponds, on Isola Longa (Isole dello Stagnone) and Vulcano island (Eolian Archipelago) represents its second and third Italian record, and the easternmost limit of its currently known distribution range.

D. mediterranea is a rare species in Italy and its sites of occurrence should be carefully protected. Unfortunately, the pond in which it was found on Vulcano island is threatened by the management of the area, aimed at increasing the infrastructure for tourism.

\section{Simocephalus congener (Koch, 1841)}

This taxon was considered a variety, a subspecies, or even a synonym, of S. exspinosus (De Geer, 1778) by many authors (cf. Margaritora, 1985; Alonso, 1996; Flössner, 2000). According to the monograph on the genus Simocephalus by Orlova-Bienkowskaja (2001) it should be a good species. In Sicilian specimens, a high variability in the number of spines on the postabdominal claw was recorded (F. Marrone, unpubl. data). As this taxon co-exists with S. exspinosus in some sites, the possibility of hybridization between these two daphnid taxa should be taken into consideration.

\section{Moina salina Daday, 1888}

M. salina is a halophilic moinid species distributed over the Mediterranean area. Similar species (M. mongolica Daday, 1901 and M. baylyi Forrò, 1985) are distributed in Asia and Australia, respectively (Forrò, 1985). In Italy, it is currently known only from Sardinia. The Sicilian populations of M. salina are limited to the brackish swamps of southeastern Sicily and it has never been found in analogous environments on the rest of the island. Its cycle starts in November/December and is clearly precocious with respect to the other western Mediterranean populations, which develop from February to April in Sardinia (Margaritora, 1985), from spring to summer in Spain (Alonso, 1996), and from March onward in southern France (Thiéry \& Puente, 2002).

\section{Macrothrix groenlandica Lilljeborg, 1900}

Several authors (Munro Fox, 1962; Usai \& Margaritora, 1987; Alonso, 1996) consider M. hirsuticornis a species with a high morphological plasticity, and "M. groenlandica" as a "form" of the former with no taxonomic status. This opinion is reinforced by the finding of intermediate forms (Munro Fox, 1962; Usai \& Margaritora, 1987). Conversely, according to the monograph on the world Macrotrichidae by Smirnov (1992) and to the key to Euro-Asian species of the 
genus Macrothrix provided by Kotov (1999), Macrothrix groenlandica is a good species.

In the frame of the present work, $M$. groenlandica has been collected at a site where it is syntopic but not synchronic with M. hirsuticornis s.s.

\section{Alona elegans Kurz, 1875}

After the description of this taxon by Kurz (1875) on the basis of Bohemian specimens, Herbst (1964) described the subspecies A. elegans arcuata from western Germany, and Dumont \& Van de Velde (1975) described A. elegans lebes from Morocco. The main distinctive features of these subspecies are: the presence of two spines at the basis of each postabdominal claw and the lack of a small spine on the first segment of the endopodite of the second antennae in the subspecies arcuata, and the presence of an ocellus larger than the eye in the subspecies lebes. Margaritora et al. (1985) assigned the Italian specimens belonging to this taxon to the subspecies Alona elegans arcuata, and morphologically characterized the Italian populations on the basis of Sicilian specimens.

Alonso (1996) and Flössner (2000) consider the subspecies A. elegans arcuata synonymous with $A$. elegans elegans, and the lack of the small spine on the first segment of the endopodite of the second antennae as a character of the nominate subspecies, thus implicitly deeming the indication of the presence of this spine in the original description by Kurz (1875) as a mistake of Kurz himself.

According to the observations carried out by Margaritora et al. (1985) with the compound microscope, it is possible to observe two spines at the basis of the postabdominal claws. Nevertheless, observations carried out with the SEM led us to assign the Sicilian populations to the nominate subspecies sensu Alonso (1996) and to raise some doubts about the true presence of A. elegans arcuata in Italy. Actually, all the specimens we observed (more than 150 from 15 populations, including one collected in the same pond where Margaritora et al. (1985) collected the specimens for her morphological characterization) have only one spine and several setae, which may collapse, giving the impression of a second spine when observed with the light microscope (fig. 3).

Furthermore, it should be noted that A. elegans arcuata is an invalid trinomen, as the subgeneric name "arcuata" is already preoccupied by Alona arcuata G. O. Sars, 1916, a South African species. 

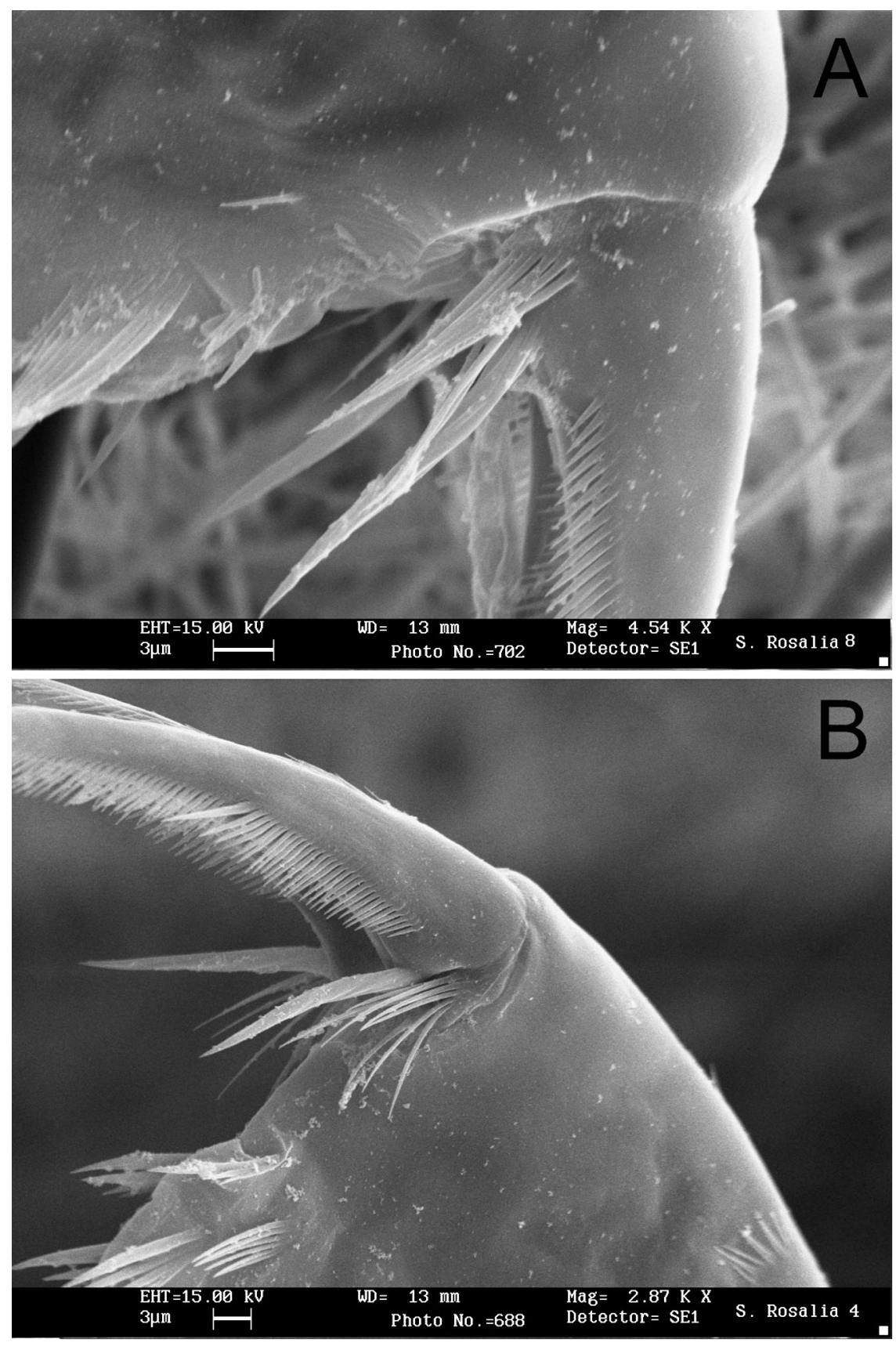

Fig. 3. A-B, SEM micrographs of the postabdominal claws of Alona elegans Kurz, 1875. 


\section{REFERENCES}

Alonso, M., 1985. Daphnia (Ctenodaphnia) mediterranea: a new species of hypersaline waters, long confused with $D$. (C.) dolichocephala Sars, 1895. Hydrobiologia, 128: 217-228.

— _, 1996. Crustacea, Branchiopoda. Fauna Iberica, 7: 1-486. (Museo Nacional de Ciencias Naturales, CSIC, Madrid).

Argano, R., M. C. Bruno, V. U. Seccherelli, V. Cottarelli, L. Mariniello, M. G. Mazzocchi, G. L. Pesce, M. Principato, G. Relini \& E. Stella, 1995. Crustacea Maxillopoda, Pentastomida. In: A. Minelli, S. Ruffo \& S. LA Posta (eds.), Checklist delle specie della fauna italiana, 28: 1-57. (Calderini, Bologna).

BenzIE, J. A. H., 2005. Cladocera: the genus Daphnia (including Daphniopsis). Guides to the Identification of the Microinvertebrates of the Continental Waters of the World, 21: 1-376. (Backhuys Publishers, Leiden).

BERZINS, B., 1954. Zur Rotatorienfauna Siziliens. Hydrobiologia, 6: 309-320.

Calvo, S., R. Barone, L. Naselli-Flores, C. Fradà Orestano, G. Dongarrà, A. LuGARO \& G. GENCHI, 1993. Limnological studies on lakes and reservoirs of Sicily. Naturalista Siciliano 27 (Suppl.): 1-292.

Castelli, G., F. Marrone, R. Barone \& L. Naselli-Flores, 2006. Crustacean dynamics in two argillotrophic, temporary ponds (north-western Sicily, Italy). Verhandlungen Internationale Vereinigung für Theoretische und Angewandte Limnologie, 29 (in press).

Cottarelli, V., F. G. Margaritora \& G. Mura, 1995. Crustacea, Branchiopoda. In: A. Minelli, S. Ruffo \& S. LA Posta (eds.), Checklist delle specie della fauna italiana, 26: 1-10. (Calderini, Bologna).

Dumont, H. J., P. Laureys \& J. Pensaert, 1979. Anostraca, Conchostraca, Cladocera and Copepoda from Tunisia. Hydrobiologia, 66: 259-274.

Dumont, H. J. \& S. V. NegREA, 2002. Introduction to the class Branchiopoda. Guides to the Identification of the Microinvertebrates of the Continental Waters of the World, 19: 1-398. (SPB Academic Publishing, The Hague).

Dumont, H. J. \& I. VAn DE Velde, 1975. Anostraca, Cladocera and Copepoda from Rio de Oro (north-western Sahara). Biol. Jb. Dodonaea, 43: 137-145.

FARANDA, F., 1977. Primo censimento delle aree destinabili ad acquacoltura in Sicilia. Atti della Società Peloritana di Scienze Fisiche, Matematiche e Naturali, 23 (Suppl.): 1-113.

Flössner, D., 2000. Die Haplopoda und Cladocera Mitteleuropas: 1-425. (Backhuys Publishers, Leiden).

FORRÒ, L., 1985. A new species of Moina from Australia (Crustacea: Cladocera). Acta Zoologica Hungarica, 31 (1-3): 111-118.

GAuthiER, H., 1928. Recerches sur la faune des eaux continentales de l'Algérie et de la Tunisie: 1-466. (Imp. Minerva, Alger).

Gurney, R., 1909. On the freshwater Crustacea of Algeria and Tunisia. Journ. Roy. Micr. Soc., 443: 273-305.

Herbst, H. V., 1964. Alona elegans arcuata n. ssp., eine neue Chidoride (Crustacea Cladocera) der deutschen Fauna. Gewässer und Abwässer, 36: 40-48.

Korovchinsky, N. M., 1992. Sididae \& Holopedidae (Crustacea: Daphniiformes), Guides to the Identification of the Microinvertebrates of the Continental Waters of the World, 3: 1-82. (SPB Academic Publishing, The Hague).

Kotov, A. A., 1999. Redescription of Macrothrix tripectinata Weisig, 1934 (Anomopoda, Branchiopoda), with a discussion of some features rarely used in the systematics of the genus. Hydrobiologia, 403: 63-80.

KuRZ, W., 1875. Dodekas neuer Cladoceren nebst einer kurzen Uebersicht der Cladocerenfauna Boehmens. Sitzungsber. Akad. Wiss. Wien (Math. Naturwiss. K1.) 70 (1): 7-88. 
MagurRan, A. E., 1988. Ecological diversity and its measurements: 1-179. (Croom Helm Itd., London).

Margaritora, F. G., 1985. Cladocera Fauna d'Italia, 23: 1-389. (Ed. Calderini, Bologna).

Margaritora, F. G., D. Crosetti \& F. Lombardi, 1985. Aspetti morfologici ed ecologici delle popolazioni italiane di Alona elegans Kurz (Crustacea, Cladocera). Istituto Lombardo (rend. Sci.), (B) 116: 45-53.

Margaritora, F. G., L. Mastrantuono, D. Corsetti \& F. Lombardi, 1982. Contributo alla conoscenza della fauna ad entomostraci delle acque interne della Sicilia. Animalia, $9(1 / 3)$ : 87-102.

MARRone, F., 2003a. Branchiopod crustaceans from circum-Sicilian islands, I: Ustica (southern Thyrrenian Sea, Italy) (Crustacea, Branchiopoda). Naturalista Siciliano, 27: 255-262.

— —, 2003b. On some cladocerans new to Sicily (southern Italy) (Crustacea Branchiopoda). Naturalista Siciliano, 27: 263-270.

Marrone, F., R. BARONE \& L. NASElli-Flores, 2005. Towards an ecological characterization of temporary ponds in a Mediterranean island (Sicily, southern Italy). Chemistry and Ecology (in press).

Marrone, F., G. Castelli, R. Barone \& L. NAselli-Flores, 2006. Ecology and distribution of calanoid copepods in Sicilian inland waters (Italy). Verhandlungen Internationale Vereinigung für Theoretische und Angewandte Limnologie, 29 (in press).

Marrone, F. \& L. NASElli-Flores, 2004. First record and morphological features of Hemidiaptomus (Occidodiaptomus) ingens (Gurney, 1909) (Copepoda Calanoida) in Italy. Jour. Limnol. 63 (2): 250-255.

— — \& — - 2005. First record of a representative of the subfamily Paradiaptominae (Copepoda Calanoida Diaptomidae) in Italy: Metadiaptomus chevreuxi (Guerne \& Richard, 1894). Journ. Limnol., 64 (1): 89-92.

Moniez, E., 1889. Note sur la faune des eaux douces de la Sicile. Feuille des Jeunes Naturalistes, 20: $17-19$.

Mouelhi, S., G. Balvay \& M. M. KraÏEM, 2000. Branchiopodes (Cténopodes et Anomopodes) et Copépodes des eaux continentales d'Afrique du Nord: inventaire et biodiversité. Zoosystema, 22 (4): 731-748.

MunRo FoX, H., 1962. On Macrothrix hirsuticornis var. groenlandica (Crustacea, Cladocera). Memorie dell'Istituto Italiano di Idrobiologia, 15: 69-77.

NASELLI-FLORES, L. \& R. BARONE, 1997. Importance of water-level fluctuation on population dynamics of cladocerans in a hypertrophic reservoir (Lake Arancio, south-west Sicily, Italy). Hydrobiologia, 360: 223-232.

NASELLI-FlORES, L., R. BARONE \& M. ZuninO, 1998. Distribution patterns of freshwater zooplankton in Sicily (Italy). Verhandlungen Internationale Vereinigung für Theoretische und Angewandte Limnologie, 26: 1973-1980.

Orlova-Bienkowskaja, M. Y., 2001. Cladocera: Anomopoda, Daphniidae: genus Simocephalus. Guides to the Identification of the Microinvertebrates of the Continental Waters of the World, 17: 1-130. (SPB Academic Publishing, The Hague).

Riccardi, N., G. Giussani, F. MARgaritora \& B. Couchaud, 2004. Population dynamics of the pioneer population of Daphnia parvula Fordyce during the invasion of Lake Candia (northern Italy). Journ. Limnol. 63 (1): 44-52.

Smirnov, N. N., 1974. Fauna of the U.S.S.R., Crustacea, Chydoridae. 1-644. (Academy of the Sciences of the U.S.S.R.; translated by Israel Program for Scientific Translations, Jerusalem).

— — 1992. The Macrothricidae of the world. Guides to the Identification of the Microinvertebrates of the Continental Waters of the World, 1: 1-143. (SPB Academic Publishing, The Hague).

_ _ 1996. Cladocera: the Chydorinae and Sayciinae (Chydoridae) of the world. Guides to the Identification of the Microinvertebrates of the Continental Waters of the World, 11: 1-197 (SPB Academic Publishing, The Hague). 
Thiéry, A. \& L. Puente, 2002. Crustacean assemblage and environmental characteristics of a man-made solar saltwork in southern France, with emphasis on anostracan (Branchiopoda) population dynamics. Hydrobiologia, 486: 191-200.

UsAi, M. C. \& F. G. MARGARITORA, 1987. Further systematic and ecological data on Italian populations of Macrothrix hirsuticornis Norman \& Brady (Crustacea, Cladocera). Bollettino di Zoologia, 54: 35-39. 